\title{
A Comparative Study of ESTs Induced under Drought and Salinity Stress in Hyacinth Bean (Lablab purpureus)
}

\author{
S. Kokila, Varadahally R. Devaraj * \\ Dept. of Biochemistry, Central college campus, Bengaluru City University, Bengaluru, India \\ Email: *devaraj@bub.ernet.in
}

How to cite this paper: Kokila, S.K. and Devaraj, V.R. (2021) A Comparative Study of ESTs Induced under Drought and Salinity Stress in Hyacinth Bean (Lablab purpureus). American Journal of Plant Sciences, 12, 840-857.

https://doi.org/10.4236/ajps.2021.125057

Received: April 9, 2021

Accepted: May 25, 2021

Published: May 28, 2021

Copyright () 2021 by author(s) and Scientific Research Publishing Inc. This work is licensed under the Creative Commons Attribution International License (CC BY 4.0).

http://creativecommons.org/licenses/by/4.0/ (c) (i) Open Access

\begin{abstract}
Abiotic stressors like drought and salinity are major causes for loss of agricultural productivity. Comparison of expressed sesquence tags (ESTs) under different abiotic stresses provides insight into underlying mechanism of stress response, and candidate genes to improve tolerance to abiotic and biotic stresses via breading and transgenic methods. In order to identify and compare stress-specific ESTs from drought and salinity stressed Hyacinth Bean, ten days old seedlings were subjected to respective stresses and RNA was extracted from control and stressed leaves for EST identification. 31 and 12 ESTs, respectively, were characterized from leaves of drought and salinity stressed seedlings of Hyacinth Bean, Lablab purpureus by differential display RT-PCR using identical combinations of 48 primers and validated using quantitative RT-PCR. Relative fold expression was higher under salt stress than drought stress. Whereas 19 EST overexpressed under drought, 12 EST were down regulated. Of the 12 EST under salinity, 9 EST were downregulated and 3 EST upregulated. Putative functions predicted from sequence homology indicated that 11 drought specific EST corresponded to metabolic functions, and 4 of them corresponded to transcription regulation. Under salinity, 4 and 2 EST, respectively, corresponded to metabolic and RNA associated functions. Under both stresses, there were ESTs associated with unknown functions, whose characterization may throw light on the regulatory mechanism. Differing number of ESTs differentially expressed under drought and salt stress, and their predicted functionalities, suggested distinct set of response genes involved under these two stresses, despite a good number of physiological players being common. From the predicted functions of ESTs, the paper attempts to explain the possible mechanism of response of Hyacinth Bean to these two stresses.
\end{abstract}




\section{Keywords}

Hyacinth Bean, Drought, Salinity, DDRT-PCR, ESTs

\section{Introduction}

Growing economy in many ways has led to climatic change by increasing global temperature, thereby rise in sea level resulting in increased salinity of groundwater and arid land [1]. Also, increase in global temperature has increased frequency of drought [2] posing a big challenge for agriculture [3]. Drought and salinity affected soils contain high concentration of ions such as chloride, sodium, calcium and magnesium in soil [4] or are nutrient deficient. Thereby, forcing the use of chemical fertilizers leading to increased cost of crop production environmental pollution. Breeding techniques have been beneficial in creating new cultivars resistant to drought and salinity. Also, understanding the tolerant genotypes response towards stress gives insights into improving the tolerance of crops.

Plant response to drought and salinity have been studied in terms of alterations in metabolism [5], detoxification [5], ABA induced response [6], proteome [7], transcriptome [8]. Transcriptome networks [9] and differential gene expression studies with model plants under abiotic stress [10] [11] have provide candidate genes for improving tolerance and productivity. Plant hormones play a role in inducing osmotic effects eliciting overlapping responses under drought and salinity [12]. Transcription factor families like NAC [13], WRKY [14], DERB [15] [16], are reported to be differentially regulated under stress. Specific protein like defensins, SpPKE1 [17], cysteine proteases [18], RING finger protein [19] an E3 ubiquitin ligase [20] and genes modified using RNAi mediated gene silencing [21] are known to increase tolerance towards abiotic stress.

Among food crops, legumes form a major source of protein and contribute to enhancement of soil quality through their nitrogen fixing ability. A Fabaceae member, Lablab purpureus L. (Hyacinth Bean) HA4 variety is extensively grown in south India for its pods, and previous reports have indicated its tolerance to drought [22] and salinity [23]. Transcriptomic variations, in root tissue, under drought stress [24] have given insight into the expression pattern. A comparative account of leaf specific transcripts expressed under drought and salinity stress in Lablab purpureus L. (Hyacinth Bean) variety HA4, are described herein with the objective of delineating the mechanism of stress response in terms of differentially expressed ESTs.

\section{Material and Methods}

\subsection{Plant Growth, Stress Induction and Total RNA Isolation}

The seeds of L. purpureus (cv. HA-4) were obtained from National Seed Project, University of Agricultural Sciences, GKVK, Bangalore, India. Seeds were surface 
sterilized with $0.1 \%(\mathrm{w} / \mathrm{v})$ mercuric chloride for $30 \mathrm{~s}$, rinsed immediately with distilled water several times and imbibed overnight in distilled water. The overnight-soaked seeds were sown in plastic trays containing vermiculite and acid-washed sand $(1: 1 \mathrm{w} / \mathrm{w})$ and irrigated daily with distilled water.

The germination was carried out under natural greenhouse conditions; day/night temperature and relative humidity were $30 / 25^{\circ} \mathrm{C}$, and $75 / 70 \%$, respectively. The average photoperiod was $12 \mathrm{~h}$ light/12 h dark. Plants were grown for 10 days before inducing stress. Drought stress was induced by withdrawing water for 6 Days whereas control plants were watered. Salt stress was induced using half strength Hoagland media with $300 \mathrm{mM} \mathrm{NaCl}$, and $150 \mathrm{mM} \mathrm{CaCl}_{2}$ for $48 \mathrm{~h}$. Control plants were grown in half strength Hoagland media without $300 \mathrm{mM}$ $\mathrm{NaCl}$. After stress exposure leaves were collected from both control and stress plants. The samples were immediately ground to a fine powder in liquid nitrogen and used for total RNA isolation. Total RNA was isolated using Tri-Reagent (Sigma-Aldrich) according to the manufacturer's instructions. The quality of total RNA was observed by electrophoresis on 1.5\% Formaldehyde-MOPS gel. The purity was assessed by reading the A260/A280 ratios and A260/A230 ratios using Biomate 3S UV-Visible spectrophotometer (Thermo Scientific).

\subsection{Differential Display Reverse Transcription Polymerase Chain Reaction}

Differential display was performed according to the method of Liang and Parde [25] with minor modifications. Total RNA was treated with RNase free DNase-I (0.1 U per mg RNA for $30 \mathrm{~min}$ ) to remove the contaminating genomic DNA. In brief, first strand cDNAs was synthesized using $2 \mu \mathrm{g}$ of Total RNA and $10 \mathrm{mM}$ oligo dT primer. Initial incubation was at $70^{\circ} \mathrm{C}$ for $5 \mathrm{~min}$ followed by quick chilling on ice. To this, 40 units of Superscript ${ }^{\mathrm{tm}}$ II RNase H RT (Thermo Scientific), 20 units RNasin (Thermo Scientific), $0.5 \mathrm{mM}$ dNTPs (Thermo Scientific) and $1 \mathrm{X}$ reverse transcriptase reaction buffer $(250 \mathrm{mM}$ Tris- $\mathrm{HCl}, \mathrm{pH} 8.3,250 \mathrm{mM}$ $\mathrm{KCl}, 20 \mathrm{mM} \mathrm{MgCl}_{2}$ and $50 \mathrm{mM} \mathrm{DTT}$ ) were added and made up to final volume of $20 \mu \mathrm{L}$.

The reaction was performed in Eppendorf master cycler by incubating at $40^{\circ} \mathrm{C}$ for $60 \mathrm{~min}$, and terminated by heating at $70^{\circ} \mathrm{C}$ for $10 \mathrm{~min}$. All cDNA samples were stored at $-80^{\circ} \mathrm{C}$ until further use. A total of three anchor primer and 16 arbitrary primer (Table 1) were used for DDRT-PCR. Amplification was carried out in a final reaction volume of $50 \mu \mathrm{L}$ containing $1 \mu \mathrm{L}$ of the cDNA as template, $0.5 \mathrm{U}$ Taq DNA polymerase (Thermo Scientific), $12.5 \mathrm{mM}$ each of specific arbitrary primer and anchor primer with restriction sites of BamHI and HindIII, respectively. $0.1 \mathrm{mM}$ dNTPs and $1 \mathrm{x}$ Taq DNA polymerase reaction buffer $(10 \mathrm{mM}$ Tris- $\mathrm{HCl}, \mathrm{pH} 9.0,1.5 \mathrm{mM} \mathrm{MgCl} 2,50 \mathrm{mM} \mathrm{KCl}$ and $0.01 \%$ gelatin). The reaction conditions were: an initial denaturation step of $95^{\circ} \mathrm{C} / 4 \mathrm{~min}$, followed by 35 cycles of $94^{\circ} \mathrm{C} / 60 \mathrm{~s}$ (denaturation), $50^{\circ} \mathrm{C}$ to $55^{\circ} \mathrm{C}$ (according to primer combination) $/ 60 \mathrm{~s}$ 
Table 1. List of primer used in DDRT-PCR.

\begin{tabular}{cc}
\hline Anchore primers & Sequence \\
\hline DST-PR/1 & AAGCTTTTTTTTTTTTTG \\
DST-PR/2 & AAGCTTTTTTTTTTTTTG \\
DST-PR/3 & AAGCTTTTTTTTTTTTTA \\
\hline Arbitrary primers & Sequence \\
\hline DST-PR/9 & AAGCTTGATTGCC \\
DST-PR/15 & AAGCTTTCCTGGA \\
DST-PR/17 & AAGCTTCTFCTGG \\
DST-PR/18 & AAGCTTACGATGC \\
DST-PR/19 & AAGCTTAGCAGCA \\
DST-PR/22 & AAGCTTCCTGCAA \\
DST-PR/23 & GAGGATCCGATTGCC \\
DST-PR/24 & GAGGATCCCAAGACC \\
DST-PR/25 & CGGGATCCTATTTAT \\
DST-PR/26 & GCGGATCCCGACTGT \\
DST-PR/27 & GTGGATCCGCCTTTA \\
DST-PR/28 & GTGGATCCCTTTGGT \\
DST-PR/29 & CAGGATCCGCACCAT \\
DST-PR/30 & CAGGATCCAGAGGCA \\
DST-PR/31 & CTGGATCCTCATATG \\
DST-PR/32 & \\
\hline & \\
\hline & \\
\hline
\end{tabular}

for annealing and $72^{\circ} \mathrm{C} / 60$ s for extension and $72^{\circ} \mathrm{C}$ for 15 min for final extension. Each reaction was run in triplicate, and products obtained were subjected to denaturing $6 \%$ urea gel electrophoresis at a voltage of $0.45 \mathrm{~V} / \mathrm{cm}^{2}$ for $12 \mathrm{~h}$ at room temperature. DNA was visualized by staining with ethidium bromide and documented using Alpha Imager gel doc. Differential bands were excised and cloned into pGEM-T-easy vector (Promega) according to manufacturer's instructions. Plasmid expressing the band of interest was sequenced on an automated sequencer (ABI PRISM 3700) using Bio Rad Taq cycle sequencing kit (Amersham Pharmacia Biotech,). Sequence analysis was performed using BLASTn (http://www.ncbi.nlm.nih.gov/blast). All of these ESTs were submitted to the dbEST database at NCBI (http://www.ebi.ac.uk).

\subsection{Quantitative Real Time PCR}

qRT-PCR was carried out using iQ SYBR green supermix (Biorad, India) on Biorad iQ5 Multicolor Real Time PCR Detection System. The reaction mix contained $0.5 \mu \mathrm{L}$ cDNA, $10 \mu \mathrm{L} 2 \mathrm{X}$ SYBR green mix, $0.5 \mu \mathrm{L}$ of $1 \mu \mathrm{M}$ forward primer and $0.5 \mu \mathrm{L}$ of $1 \mu \mathrm{M}$ reverse primer in $20 \mu \mathrm{L}$ reaction volume. The cycling conditions were: initial denaturation of $95^{\circ} \mathrm{C} / 3$ min followed by 40 repetitive cycles at 
$95^{\circ} \mathrm{C}$ for $20 \mathrm{~s}$ for denaturation, $60^{\circ} \mathrm{C}$ for $30 \mathrm{~s}$ for annealing (according to primer combination) and $72^{\circ} \mathrm{C}$ for $30 \mathrm{~s}$ for extension. Melt curve analysis was performed at $55^{\circ} \mathrm{C}-95^{\circ} \mathrm{C}$. $\beta$-Actin was used as the endogenous control and analysis was carried out in three replicates. The $\mathrm{Cq}$ values were converted to relative quantities using the formula: $2-\Delta \Delta \mathrm{Ct}$ [26].

\section{Results}

DDRT-PCR was performed using 48 combinations of primers. Bands with clear differential expression were excised from polyacrylamide gels, amplified and sequenced. All obtained ESTs were submitted to NCBI EST database. After removing the redundant sequences, 31 differentially expressed ESTs were obtained under drought stress and 12 under salinity stress. All the sequenced fragments were of the expected length as ascertained from their positions in the gel and ranged between 98 - $423 \mathrm{bp}$ for ESTs under drought, and 137 - $311 \mathrm{bp}$ for ESTs under salinity stress. Sequence homology of the expressed fragments expressed under stress ranged between $73 \%$ - 93\% similarity to sequence in Reference mRNA database. The ESTs showed similarity to sequences from legume family. Quantitative real time PCR was carried out to ascertain expression pattern (Figure 1 and Figure 2). The ESTs from salinity stress showed homology to genes encoding sugar transporter, ion transporter, chromatin remodeling components and RNA splicing components. Expression profile of salinity induced ESTs indicated that 3 ESTs were up regulated and 9 were down regulated. Eight EST corresponded to genes with putative functions (Table 2) and 4 were hypothetical

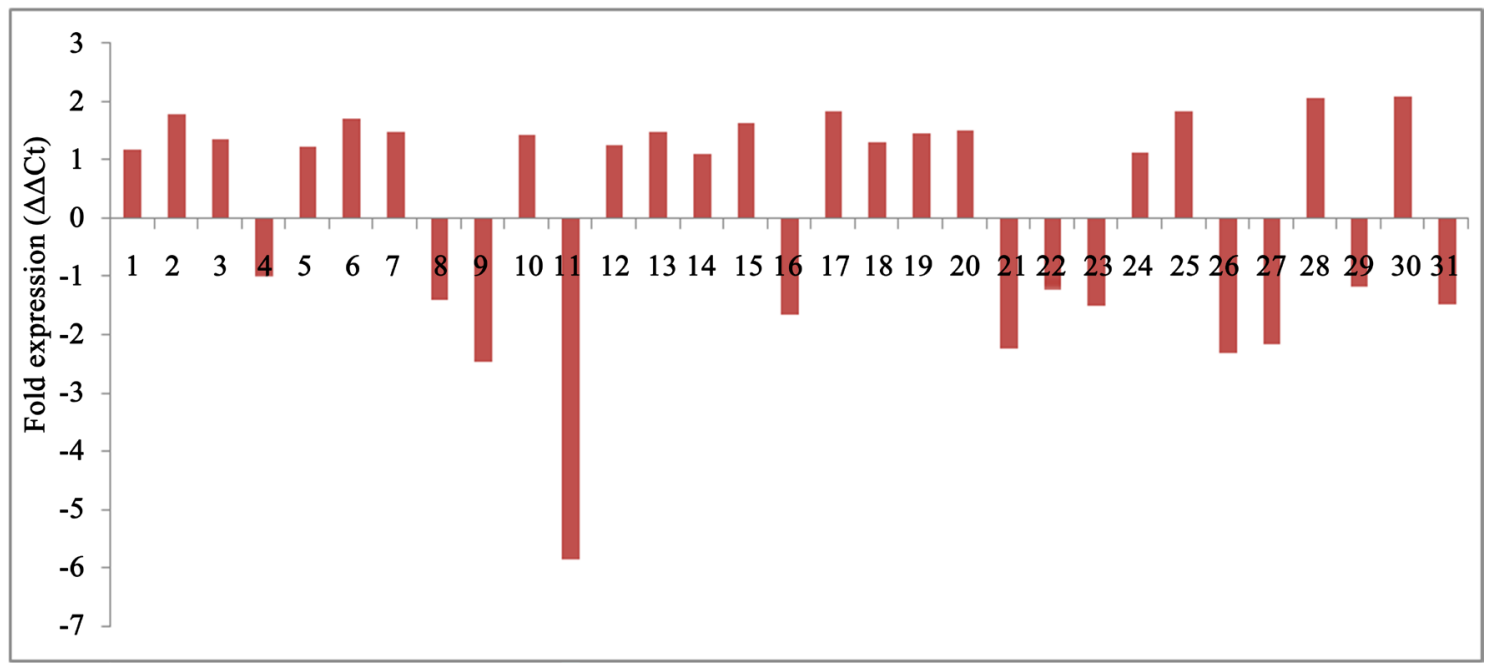

Figure 1. Differential expression of 31 ESTs under drought stress. Actin gene used as control. The ESTs expression below zero are down regulated, above zero are up regulated. Changes in gene expression are calculated using $\Delta \Delta \mathrm{Ct}$ method. The plotted values are average of triplicates. (On the X-axis are the EST (Number assigned and their corresponding Genbank accession number are; 1-JZ515981, 2-JZ515982, 3-JZ168400, 4-JZ168401, 5-JZ168402, 6-JZ168403, 7-JZ168404, 8-JZ168405, 9-JZ168406, 10-JZ168407, 11-JZ168408, 12-JZ168409, 13-JZ515983, 14-JZ515984, 15-JZ515985，16-JZ515986，17-JZ515987，18-JZ515988，19-JZ515989，20-JZ515990，21-JZ546398，22-JZ546399, 23-JZ546400，24-JZ546401，25-JZ546402，26-JZ546404，27-JZ546405，28-JZ546406, 29-JZ546407, 30--JZ546408 and 31-JZ546409). 


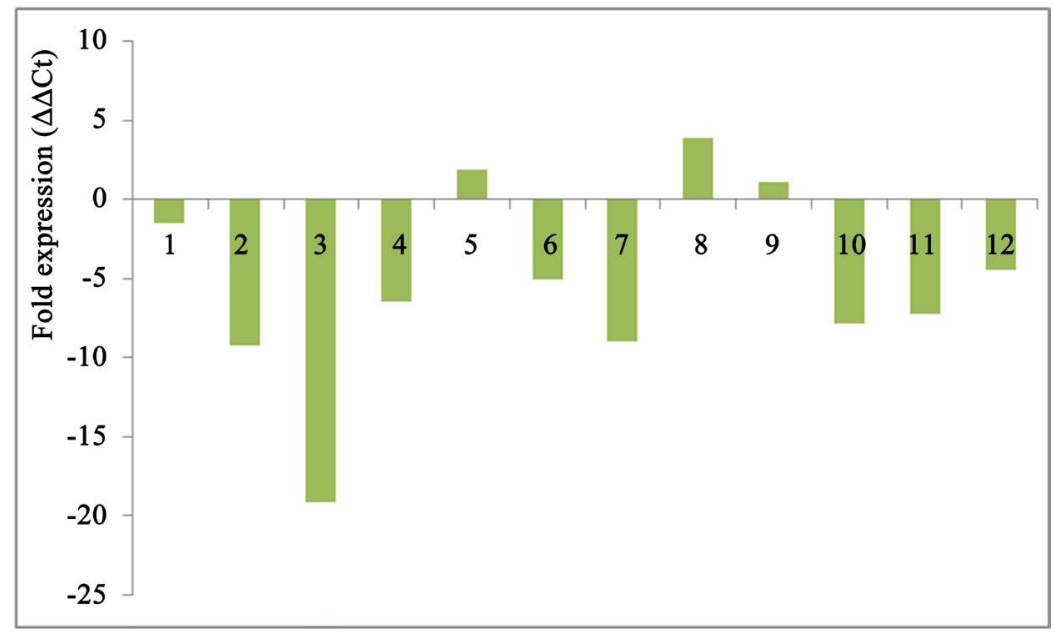

Figure 2. Differential expression of 12 ESTs transcripts under salinity. Actin gene is used as control. The ESTs with fold expression below zero are down regulated, above zero are up regulated. Changes in gene expression are calculated using $\Delta \Delta \mathrm{Ct}$ method. The plotted values are average of triplicates. On the X-axis are the EST (Number assigned and their corresponding Genbank accession number are 1-JZ515991, 2-JZ515992, 3-JZ515993, 4-JZ515995, 5-JZ515996, 6-JZ515997, 7-JZ515998, 8-JZ515999, 9-JZ516000, 10-JZ516001, 11-JZ516002 and 12-JZ516003).

Table 2. List of ESTs differentially regulated under drought and salinity stress.

\begin{tabular}{|c|c|c|c|c|c|c|}
\hline $\begin{array}{l}\text { Up/Down } \\
\text { regulated. }\end{array}$ & $\begin{array}{c}\text { GenBank } \\
\text { accession } \\
\text { number }\end{array}$ & Similar protein & Size (bp) & E value & Condition & $\begin{array}{c}\text { Fold } \\
\text { change. }\end{array}$ \\
\hline \multicolumn{7}{|c|}{ Upregulated ESTs } \\
\hline \multirow{8}{*}{$\begin{array}{l}\text { Metabolism } \\
\text { associated }\end{array}$} & JZ546402 & Poly (A) binding protein (PABP) RBP45 & 360 & $9 e-58$ & Drought & 1.8 \\
\hline & JZ515990 & Mitochondrial ATP synthase F1 complex assembly factor2 & 194 & $9 e-28$ & Drought & 1.5 \\
\hline & JZ515983 & carbon catabolite repressor protein 4 like (CCRP) & 205 & $8 e-41$ & Drought & 1.474 \\
\hline & JZ168409 & cell wall associated hydrolase & 127 & $2 e-49$ & Drought & 1.265 \\
\hline & JZ515981 & Cytochrome c oxidase (COX) & 149 & $3 e-18$ & Drought & 1.17 \\
\hline & JZ546401 & Ubiquitin carboxyl-terminal hydrolase & 267 & $1 e-80$ & Drought & 1.14 \\
\hline & JZ515984 & vesicle associated membrane protein 727 like. VAMP727 & 387 & $1 \mathrm{e}-110$ & Drought & 1.117 \\
\hline & JZ515999 & plastidic glucose transporter & 234 & $9 e-23$ & Salinity & 2.907 \\
\hline \multirow{4}{*}{$\begin{array}{l}\text { Transcriptional } \\
\text { regulators }\end{array}$} & JZ546408 & mediator of RNA polymerase II transcription subunit 26b-like & 106 & 0.17 & Drought & 2.09 \\
\hline & JZ168404 & MYB transcription factor & 149 & $5 e-23$ & Drought & 1.47 \\
\hline & JZ515989 & Calmodulin-binding Transcription Activator 3 like (CAMTA3) & 302 & $7 e-83$ & Drought & 1.453 \\
\hline & JZ515988 & nuclear TF-Y subunit A-7 like & 204 & $6 e-05$ & Drought & 1.319 \\
\hline \multirow{2}{*}{ Ribosome associated } & JZ515982 & 30 S ribosomal subunit protein S7 & 148 & $7 e-50$ & Drought & 1.8 \\
\hline & JZ168407 & Ribosomal protein L22 & 261 & $9 e-86$ & Drought & 1.443 \\
\hline \multicolumn{7}{|l|}{ Down regulated ESTs } \\
\hline \multirow{3}{*}{$\begin{array}{l}\text { Metabolism } \\
\text { associated }\end{array}$} & JZ546398 & clatherin interactor EPSIN 1-like protein & 157 & $1 e-25$ & Drought & 2.234 \\
\hline & $\mathrm{JZ168405}$ & maturase $\mathrm{K}$ & 532 & $1 e-151$ & Drought & 1.4 \\
\hline & JZ546400 & E3 ubiquitin-protein ligase PUB22-like & 161 & $2 \mathrm{e}-15$ & Drought & 1.48 \\
\hline
\end{tabular}




\begin{tabular}{|c|c|c|c|c|c|}
\hline & JZ546405 MLP -like protein 28 -like & 230 & $3 e-09$ & Drought & 2.158 \\
\hline & JZ515992 5'-adenylyl sulphate reductase & 192 & $2 \mathrm{e}-37$ & Salinity & 9.25 \\
\hline & JZ515991 cell wall associated hydrolase & 272 & $2 e-73$ & Salinity & 1.48 \\
\hline & JZ515993 nitrate transporter 1.5 like & 294 & $9 e-62$ & Salinity & 1.8 \\
\hline \multirow{4}{*}{$\begin{array}{l}\text { Chloroplast } \\
\text { associated }\end{array}$} & JZ546399 short chain dehydrogenase TIC32 & 98 & $4 e-25$ & Drought & 1.21 \\
\hline & JZ168408 chlorophyll a/b binding protein & 196 & $8 e-11$ & Drought & 5.85 \\
\hline & JZ546409 Photosystem II CP47 & 308 & $3 e-116$ & Drought & 1.474 \\
\hline & JZ516002 chlorophyllide-b reductase & 329 & $1 e-31$ & Salinity & 7.6 \\
\hline \multirow{3}{*}{ RNA associated } & JZ168401 rRNA-processing protein EBP2 & 128 & $2 \mathrm{e}-07$ & Drought & 1 \\
\hline & JZ515998 pre-mRNA-splicing factor CWC22 & 179 & $5 e-18$ & Salinity & 8.9 \\
\hline & JZ515997 pentapeptide repeat protein family & 269 & $2 e-72$ & Salinity & 1.839 \\
\hline $\begin{array}{l}\text { Chromatin associated } \\
\text { protein }\end{array}$ & JZ516003 SSRP1 of FACT chromatin remodeling complex & 137 & $3 e-43$ & Salinity & 4.438 \\
\hline
\end{tabular}

proteins. Thirty-one ESTs characterized under drought stress exhibited homology to transcription factors, chlorophyll, ribosome and RNA polymerase associated proteins, enzymes involved in protein degradation and general metabolism. Expression profile of ESTs indicated that 19 ESTs were up regulated and 12 down regulated. While 21 of the EST corresponded to genes with putative functions (Table 2) 10 of them corresponded to hypothetical proteins.

\section{Discussion}

Lablab purpureus has been reported to exhibit quantitative and qualitative variations in biochemical markers of stress responses under salinity and drought stress [22] [23]. These variations indicate distinctive set of players involved in stress perception and response biochemistry. This is also corroborated by distinct set of differentially expressed ESTs characterized under drought and salinity stress using DDRT-PCR, employing a common set of 48 primers. The distinction was also clear from the fact that 31 ESTs were characterized under drought stress, while only 12 ESTs were characterized under salinity stress relative to their respective controls. Annotation of ESTs, suggested different functionalities involved in drought and salt stress response in Lablab purpureus. Even among 12 ESTs differentially expressed under salinity stress, none of them were observed to be similar to those identified under drought stress (Table 2). Broadly the annotated ESTs, from both drought and salt stress, were associated with metabolism, photosynthesis, energy production and post transcriptional regulation, such as alteration in mRNA levels.

Metabolic adjustment is crucial to cope with abiotic stress. These changes may involve selective regulation of genes associated with the maintenance of metabolite levels. While synthesis and storage of starch in plastids takes place during the day, under applied drought, the increase in demand for energy and reduced 
photosynthetic ability induces the breakdown of starch [27]. The breakdown product, Glucose-6-phosphate, is transported across the plastidic membrane via the Glucose-6-phosphate transporter [27]. Upregulation of EST homologous to Plastidic Glucose Transporter suggested breakdown of starch under salinity stress. A homologue of this transporter has been reported to be upregulated in Arabidopsis thaliana during increased sink demand [28] [29] [30].

Transcript abundance of several genes encoding mitochondrial proteins are known to be upregulated in response to stress [31]. An EST homologous to cytochrome-c oxidase (COX) was differentially regulated under drought stress with 1.17-fold over expression. COX expression has been shown to be associated with thermotolerance as observed in Arabidopsis thaliana [32] [33] and monocots such as maize [34]. Therefore, upregulated EST suggested may also contribute to drought tolerance of Lablab purpureus, also Lablab is also known for thermotolerance which has been shown through biochemical studies [35] COX may also play a role. Another EST showing homology to F1 complex assembly factor 2-like of F0F1 ATP synthase known to help in the stabilization of ATPase complex and facilitate the formation of ATP [36] [37], was upregulated under drought, is in conformity with increased demand for ATP during stress.

Catabolite repression is a general mechanism utilized by prokaryotes and lower eukaryotes to regulate carbon and nitrogen metabolism. Plant homologs are involved in catabolite regulation of various metabolites [38] [39]. Upregulation of EST homologues to CCRP suggested a vital role for its mRNA turnover during drought stress [33]. Plants respond to environmental cues by altering rigidity of the cell wall. Cell wall hydrolases have been shown to be crucial in cell wall dynamics [40] [41]. While an EST homologue to cell wall hydrolase was upregulated under drought, another homologue was down regulated under salinity stress. While upregulation of hydrolases has been reported to have protective effects under drought stress [42] their down regulation has been found to be effective under salinity stress [43].

Cell volume is modulated by alteration in plasma membrane size which is due to dynamics of endocytic vesicles. Endocytosis in plants can be mediated by formation of clathrin-dependent vesicles or clathrin-independent vesicles. EPSIN (Eps15 interactor) has been identified as a key protein under clathrinmediated endocytosis in flowering plants [44]. In Lablab purpureus, the downregulation of EPSIN homologue indicated the role of clathrin independent endocytosis under drought stress. Another vesicle associated EST showed homology to VAMP727, which is associated with ARA6 a QSNARE [45] [46] [47], was differentially expressed under drought stress. Overexpression under drought stress but not under salt stress, suggested different set of inducers under drought and salinity in Lablab. Dehydration leads to protein aggregation and damage [48] [49]. One of the key enzymes in protein turnover, ubiquitin carboxy-terminal hydrolase, catalyses hydrolysis of ubiquitin polymers to monomers and release of ubiquitin from tagged protein [50]. An EST showing homology to this gene was 
upregulated under drought as observed in Brassica napus [51]. E3 ligase is a key protein which transfers the ubiquitin onto target protein, an EST corresponding to PUB22 U-box-containing E3 ligase is down-regulated under drought. First identified in Arabidopsis [52], PUB22 expression was shown to have negative influence on water stress response [52]. The increased activity of hydrolase and reduced E3 ligase indicated the reduction in protein turnover under drought in L. purpureus.

Survival of plants under stress is critically dependent on storage and utilization of assimilated elements such as Sulphur and Nitrogen [53]. EST homologous to Adenosine-5'-phosphosulfate-kinase (APSK), involved in sulphur metabolism, and nitrate transporter (NRT 1.5) 1.5 like were down regulated under salinity stress. Reduced APSK would result in reduced 3'-phosphoadenosine 5'-phosphosulfate (PAPS), a principal sulphur donor in metabolism of sulphur containing compounds [54] [55]. Reduction in NRT 1.5 like would cause non mobilization of nitrate stores, with reduction in plant growth [56]. Similar downregulation of NRT homologue has been reported for Arabidopsis thaliana [57] under cadmium stress, suggesting the possibility of similar molecular signals prevailing under salinity and heavy metal stress.

Stability and/or turnover of mRNA is one of the factors influencing gene expression under normal and stressed conditions [58]. Differential expression of a homologue of poly A binding protein RBP45 under drought stress suggested its role in stability of mRNA under drought [59]. But a similar response was not observed under salt stress when identical set of primers were employed for DDRT-PCR, although physiological response to dehydration by drought and salinity have been reported to be similar.

Transcription factors play key role in regulation of gene expression [60]. ESTs corresponding to MYB was upregulated under drought stress. MYB transcription factors are known to be involved in cold tolerance [61], stress response [62], ABA induced drought tolerance mechanism [63]. Another EST homologue to NF-Y A7 like has shown to be important in embryonic development, plastid biogenesis, abiotic stress tolerance [64] [65]. Upregulation of MYB and NF-Y A7 like members strongly indicate priming of transcription regulation under drought stress in Lablab purpureus.

Another EST homologous to transcriptional activator CAMTA3, a major regulator in biotic defence [66] [67] and regulator of rapid stress response element [68] was differentially expressed under drought. Considering the fact that CAMTA3 mutants accumulate greater DNA damage [69], its upregulation in Lablab purpureus suggested its protective role under drought stress. As most of the gene regulation by transcription factors are mediated by mediator complexes, up and down regulation of mediators [70] [71] [72] [73] would have an impact on the extent of regulation by a given transcription factor [74]. Upregulation of homologue of Med26 under drought suggested its positive effect in drought tolerance. 
Post transcriptional regulation via siRNA and miRNA have been shown to contribute to stress response either positively, or negatively [75] [76]. Down regulation of a homologue of Maturase $\mathrm{K}$ under drought stress, which is known to be involved in splicing group II introns, in relation to plant development indicated non processing of the transcripts [77] [78] and has protective role in Lablab purpureus. As part of post transcriptional regulation of gene expression, modification of mRNA also plays a key role. Pentatricopeptide repeat proteins (PPR) are known to be associated with mRNA splicing and processing components of organelles, and overexpression of a PPR gene in A. thaliana has been shown to contribute to tolerance to salinity stress [79] [80] [81]. Down regulation of an EST homologous to pentapeptide repeat protein family (PPRP family) and pre-mRNA-splicing factor (CWC22) under salinity, indicate reduced stability of mRNAs under salt stress.

Abiotic stress responses are also known to be epigenetically regulated [82]. A homologue of SSRP1, which is known to associate with FACT (Facilitates chromatin transcription complex) complex [83] [84], required for transcription elongation by RNA polymerase II, was down regulated under salinity. This indicated significant role for FACT mediated epigenetic regulation under salt stress.

Environmental stress has been shown to influence ribosomal synthesis [85]. Two EST homologous of ribosomal subunits, chloroplast encoded S7 and the nucleus encoded L22, were upregulated suggesting the dynamics of ribosome under drought stress. A similar observation with upregulation of S7 has been observed in Tomato [86]. An EST homologous to rRNA-processing protein EBP2 mRNA [87] [88] showed down regulation under drought. In Arabidopsis this protein expression is altered in salt hypersensitive mutant 9 (sahy9) mutant under salinity stress [89]. The down regulation of predicted EBP2 in Lablab purpureusmight slowdown the progression of mitosis and effect salinity induced ribosomal protein alteration in biogenesis.

Drought and salinity stress are known to affect the photosynthetic capacity, which is linked to chlorophyll content [90]. Two ESTs one homologous to chlorophyll a/b binding protein, and another showing homology to Photosystem II CP47, a component of Light harvesting complex component was down regulated under drought stress, suggesting reduced photosynthetic capacity in Lablab purpureus. Declined photosynthetic activity due to down regulation of LHCB protein family has been shown in Arabidopsis [91] and pepper [92].

Downregulation of salt stress specific differentially expressed EST, homologous to chlorophyll reductase in Lablab, which indicated delay in senescence [93] [94] under salt stress as observed in stay green phenotypes of Oryza sativa [95]. Another EST homologous to TIC32, a short chain dehydrogenase, which is part of Toc-Tic complex involved in regulation of protein import [96] in response to calcium sensing was down regulated under drought. A similar down regulation has been observed in $O$. sativa under drought stress [97]. Apart from these known homologs, there were ESTs matching the unknown function giving 
a scope for identification of new roles.

Previous studies have shown that Lablab purpureus exhibits more or less similar pattern of biochemical parameters such as antioxidants and antioxidant enzymes under drought and salt stress. However, the foregoing discussion shows a contrasting response in terms of relative abundance of transcripts under these two conditions. Further, the transcripts identified under these two conditions were altogether different despite identical set of primers employed in DDRT-PCR method. Compared to other study on root transcriptome, only one EST (MYB) showed similarity. Therefore, it can be concluded that, at transcription level, distinct signalling molecules and elicitors are employed by the plants under drought and salinity stress. Nevertheless, the observed levels of transcripts may not always indicate the expected levels of translation products, as the stability of mRNAs and translational regulation further add a layer of regulation to stress. A clear picture may require exhaustive transcript profiling and study of epigenetic regulation to compare the molecular events that distinguish response of the plant to drought and salt stress.

\section{Acknowledgements}

The authors are grateful to Department of Science and Technology, New Delhi, for providing financial assistance (SR/SO/BB-72/2007, dated 14.01.2009). Authors are also grateful to GKVK, Bengaluru, for providing seeds and the Department of Biological Science, IISc Bangalore, for their generosity to allow us use central facility.

\section{Conflicts of Interest}

The authors declare no conflicts of interest regarding the publication of this paper.

\section{References}

[1] Dagar, J.C., Sharma, P.C., Chaudhari, S.K., Jat, H.S. and Sharif, A. (2016) Climate Change Vis-a-Vis Saline Agriculture: Impact and Adaptation Strategies. In: Dagar J.C., Sharma, P.C., Sharma, D.K. and Singh, A.K., Eds., Innovative Saline Agriculture, Springer, New Delhi, 5-53. https://doi.org/10.1007/978-81-322-2770-0_2

[2] Dasgupta, S., Hossain, M.M., Huq, M. and Wheeler, D. (2018) Climate Change, Salinization and High-Yield Rice Production in Coastal Bangladesh. Agricultural and Resource economic Review, 47, 66-89. https://doi.org/10.1017/age.2017.14

[3] Yan, F., Zhu, Y., Zhao, Y., Wang, Y., Li, J., Wang, Q. and Liu, Y. (2020) De Novo Transcriptome Sequencing and Analysis of Salt-, Alkali-, and Drought-Responsive Genes in Sophora alopecuroides. BMC Genomics, 21, Article No. 423. https://doi.org/10.1186/s12864-020-06823-4

[4] Mengel, K., Kirkby, E.A., Kosegarten, H. and Appel, T. (2001) Principles of Plant Nutrition. Kluwer Academic Publishers, Springer, Dordrecht. https://doi.org/10.1007/978-94-010-1009-2

[5] Muscolo, A., Junker, A., Klukas, C., Weigelt-Fischer, K., Riewe, D. and Altmann, T. (2015) Phenotypic and Metabolic Responses to Drought and Salinity of Four Con- 
trasting Lentil Accessions. Journal of Experimental Botany, 66, 5467-5480. https://doi.org/10.1093/jxb/erv208

[6] Zhu, J.K. (2002) Salt and Drought Stress Signal Transduction in Plants. Annual Review of Plant Biology, 53, 247-273.

https://doi.org/10.1146/annurev.arplant.53.091401.143329

[7] El Rabey, H.A., Al-Malki, A.L., Abulnaja, K.O. and Rohde, W. (2015) Proteome Analysis for Understanding Abiotic Stress (Salinity and Drought) Tolerance in Date Palm (Phoenix dactylifera L.). International Journal of Genomics, 2015, Article ID: 407165. https://doi.org/10.1155/2015/407165

[8] Hu, W., Ding, Z., Tie, W., Yan, Y., Liu, Y., Wu, C., Liu, J., Wang, J., Peng, M. and Jin, Z. (2017) Comparative Physiological and Transcriptomic Analyses Provide Integrated Insight into Osmotic, Cold, and Salt Stress Tolerance Mechanisms in Banana. Scientific Reports, 7, Article No. 43007. https://doi.org/10.1038/srep43007

[9] Shinozaki, K. and Yamaguchi-Shinozaki K. (2007) Gene Networks Involved in Drought Stress Response and Tolerance. Journal of Experimental Botany, 58, 221-227. https://doi.org/10.1093/jxb/erl164

[10] Haile, M. and Hee, W. (2018) Transcriptome Profiling of the Coffee (C. arabica L.) Seedlings under Salt Stress Condition. Journal of Plant Biotechnology, 45, 45-54. https://doi.org/10.5010/JPB.2018.45.1.045

[11] Mun, B.G., Lee, S.U., Park, E.J. Kim H.H., Hussain, A., Imran, Q.M., Lee, I.J. and Yun, B.J. (2017) Analysis of Transcription Factors among Differentially Expressed Genes Induced by Drought Stress in Populus davidiana. 3 Biotech, 7, Article No. 209. https://doi.org/10.1007/s13205-017-0858-7

[12] Bashir, K., Matsui, A., Rasheed, S. and Seki, M. (2019) Recent Advances in the Characterization of Plant Transcriptomes in Response to Drought, Salinity, Heat, and Cold Stress. F1000Research, 8, 1-8. https://doi.org/10.12688/f1000research.18424.1

[13] Guérin, C., Roche, J., Allard, V., Ravel, C., Mouzeyar, S. and Bouzidi, M.F. (2019) Genome-Wide Analysis, Expansion and Expression of the NAC Family under Drought and Heat Stresses in Bread Wheat (T. Aestivum L.). PLoS ONE, 14, e0213390. https://doi.org/10.1371/journal.pone.0213390

[14] Singh, A., Sonah, H., Singh, P.K., Sharma, A.K., Singh, N.S., Sonah, H., Deshmukh, R. and Sharma T.R. (2019) Understanding the Role of the WRKY Gene Family under Stress Conditions in Pigeon Pea (Cajanus Cajan L.). Plants, 8, Article No. 214. https://doi.org/10.3390/plants8070214

[15] Sakuma, Y., Liu, Q., Dubouzet, J.G., Abe, H., Shinozaki, K. and Yamaguchi-Shinozaki, K. (2002) DNA-Binding Specificity of the ERF/AP2 Domain of Arabidopsis DREBs, Transcription Factors Involved in Dehydration- and Cold-Induci ble Gene Expression. Biochemical and Biophysical Research Communications, 290, 998-1009. https://doi.org/10.1006/bbrc.2001.6299

[16] Nakashima, K., Ito, Y. and Yamaguchi-Shinozaki, K. (2009) Transcriptional Regulatory Networks in Response to Abiotic Stresses in Arabidopsis and Grasses. Plant Physiology, 149, 88-95. https://doi.org/10.1104/pp.108.129791

[17] Li, J., Chen, C., Wei, J., Pan, Y., Su, C. and Zhang, X. (2019) SpPKE1, a Multiple Stress-Responsive Gene Confers Salt Tolerance in Tomato and Tobacco. International Journal of Molecular Sciences, 20, Article No. 2478. https://doi.org/10.3390/ijms20102478

[18] Chen, H.J., Su, C.T., Lin, C.H., Huang, G.J. and Lin, Y.H. (2010) Expression of Sweet Potato Cysteine Protease SPCP2 Altered Developmental Characteristics and Stress Responses in Transgenic Arabidopsis Plants. Journal of Plant Physiology, 
167, 838-847. https://doi.org/10.1016/j.jplph.2010.01.005

[19] Park, Y.C., Chapagain, S. and Jang, C.S. (2018) A Negative Regulator in Response to Salinity in Rice: Oryza sativa Salt-, ABA- and Drought-Induced RING Finger Protein 1 (OsSADR1). Plant and Cell Physiology, 59, 575-589. https://doi.org/10.1093/pcp/pcy009

[20] Fang, H., Meng, Q., Xu, J., Tang, H., Tang, S., Zhang, H. and Huang, J. (2015) Knock down of Stress Inducible OsSRFP1 Encoding an E3 Ubiquitin ligase with Transcriptional Activation Activity Confers Abiotic Stress Tolerance through Enhancing Antioxidant Protection in Rice. Plant Molecular Biology, 87, 441-458. https://doi.org/10.1007/s11103-015-0294-1

[21] Pradhan, A., Naik, N. and Sahoo, K. (2015) RNAi Mediated Drought and Salinity Stress Tolerance in Plants. American Journal of Plant Sciences, 6, 1990-2008. https://doi.org/10.4236/ajps.2015.612200

[22] D'souza, M.R. and Devaraj, V.R. (2011) Specific and Non-Specific Responses of Hyacinth Bean (Dolichos lablab) to Drought Stress. Indian Journal of Biotechnology, 10, 130-139.

[23] D'Souza, M.R. and Devaraj, V.R. (2010) Biochemical Responses of Hyacinth Bean (Lablab purpureus) to Salinity Stress. Acta Physiologiae Plantarum, 32, 341-353. https://doi.org/10.1007/s11738-009-0412-2

[24] Yao, L.M., Wang, B., Cheng, L. J. and Wu, T. L. (2013) Identification of Key Drought Stress-Related Genes in the Hyacinth Bean. PLOS ONE, 8, e58108. https://doi.org/10.1371/journal.pone.0058108

[25] Liang, P. and Pardee, A. (1992) Differential Display of Eukaryotic Messenger RNA by Means of the Polymerase Cham Reaction. Science, 257, 967-971. https://doi.org/10.1126/science.1354393

[26] Livak, K.J. and Schmittgen, T.D. (2001) Analysis of Relative Gene Expression Data Using Real-Time Quantitative PCR and the 2(-Delta Delta C(T)) Method. Methods, 25, 402-408. https://doi.org/10.1006/meth.2001.1262

[27] Weber, A.P.M. and Linka, N. (2011) Connecting the Plastid: Transporters of the Plastid Envelope and Their Role in Linking Plastidial with Cytosolic Metabolism. Annual Review of Plant Biology, 62, 53-77. https://doi.org/10.1146/annurev-arplant-042110-103903

[28] Sharkey, T.D., Laporte, M., Lu, Y., Weise, S. and Weber A.P.M. (2004) Engineering Plants for Elevated $\mathrm{CO}_{2}$ : A Relationship between Starch Degradation and Sugar Sensing. Plant Biology, 6, 280-288. https://doi.org/10.1055/s-2004-817911

[29] Smith, A.M., Zeeman, S.C. and Smith, S.M. (2005) Starch Degradation. Annual Review of Plant Biology, 56, 73-98.

https://doi.org/10.1146/annurev.arplant.56.032604.144257

[30] Durand, M., Mainson, D., Porcheron, B., Maurousset, L., Lemoine, R. and Pourtau, N. (2018) Carbon Source-Sink Relationship in Arabidopsis thaliana: The Role of Sucrose Transporters. Planta, 247, 587-611. https://doi.org/10.1007/s00425-017-2807-4

[31] Millar, A.H., Small, I.D. and Day, D.A. (2008) Mitochondrial Biogenesis and Function in Arabidopsis. Arabidopsis Book, 2008, e0111.

https://doi.org/10.1199/tab.0111

[32] Larkindale, J. and Vierling E. (2008) Core Genome Responses Involved in Acclimation to High Temperature. Plant Physiology, 146, 323-324. https://doi.org/10.1104/pp.107.112060

[33] Aghdasia, M., Smeekens, S. and Schluepman, H. (2008) Microarray Analysis of 
Gene Expression Patterns in Arabidopsis Seedlings under Trehalose, Sucrose and Sorbitol Treatment. International Journal of Plant Production, 2, 309-320. https://doi.org/10.22069/ijpp.2012.622

[34] Bruce, W.B. and Gupta R. (2008) Over-Expression of Maize COX VII Subunit for Enhanced Yield. US Patent WO 2008135603 A2. Cropdesign N.V..

[35] D'souza, M.R. and Devaraj, V.R. (2013) Induction of Thermotolerance through Heat Acclimation in Lablab Bean (Dolichos lablab). African Journal of Biotechnology, 12, 5695-5704.

[36] Walker, J.E. and Dickson, V.K. (2006) The Peripheral Stalk of the Mitochondrial ATP Synthase. Biochimica et Biophysica Acta-Bioenergetics, 1757, 286-296. https://doi.org/10.1016/j.bbabio.2006.01.001

[37] Rühle, T., Razeghi, J. A., Vamvaka, E., Viola, S., Gandini, C., Kleine, T., Schünemann, D., Barbato, R., Jahns, P. and Leister, D. (2014) The Arabidopsis Protein CGL160 Promotes Assembly of the CFO Part of the Chloroplast ATP Synthase. Plant Physiology, 165, 207-226. https://doi.org/10.1104/pp.114.237883

[38] Alderson, A., Sabelli, P.A., Dickinson, J.R., Cole, D., Richardson, M., Kreis, M., Shewry, P.R. and Halford, N.G. (1991) Complementation of Snfl, a Mutation Affecting Global Regulation of Carbon Metabolism in Yeast, by a Plant Protein Kinase cDNA. Proceedings of the National Academy of Sciences of United States of America, 88, 8602-8605. https://doi.org/10.1073/pnas.88.19.8602

[39] Ho, S.-L., Chao, Y.-C., Tong, W.-F. and Yu, S.-M. (2001) Sugar Coordinately and Differentially Regulates Growth- and Stress-Related Gene Expression via a Complex Signal Transduction Network and Multiple Control Mechanisms. Plant Physiology, 125, 877-890. https://doi.org/10.1104/pp.125.2.877

[40] Cano-Delgado, A.I., Metzlaff, K. and Bevan, M.W. (2000) The eli1 Mutation Reveals a Link between Cell Expansion and Secondary Cell Wall Formation in Arabidopsis thaliana. Development, 127, 3395-3405. https://doi.org/10.1242/dev.127.15.3395

[41] Tenhaken, R. (2015) Cell Wall Remodeling under Abiotic Stress. Frontiers in Plant Science, 5, Article No. 771. https://doi.org/10.3389/fpls.2014.00771

[42] Hori, C., Yu, X., Mortimer, J. C., Sano, R., Matsumoto, T., Kikuchi, J., Demura, T. and Ohtani, M. (2020) Impact of Abiotic Stress on the Regulation of Cell Wall Biosynthesis in Populus trichocarpa. Plant Biotechnology, 37, 273-283. https://doi.org/10.5511/plantbiotechnology.20.0326a

[43] Singh, A. and Prasad, R. (2009) Salt Stress Effects Growth and Cell Wall Bound Enzymes in Arachis hypogaea L. Seedlings. International Journal of Integrative Biology, 7, 117-123.

[44] Song, J., Lee, M.H., Lee, G., Yoo, C.M. and Hwang I. (2006) Arabidopsis EPSIN1 Plays an Important Role in Vacuolar Trafficking of Soluble Cargo Proteins in Plant Cells via Interactions with Clathrin, AP-1, VTI11, and VSR1. The Plant Cell, 18, 2258-2274. https://doi.org/10.1105/tpc.105.039123

[45] Ebine, K., Uemura, T., Nakano, A. and Ueda, T. (2012) Flowering Time Modulation by a Vacuolar SNARE via FLOWERING LOCUS C in Arabidopsis thaliana. PLoS ONE, 7, e42239. https://doi.org/10.1371/journal.pone.0042239

[46] Ebine, K., Fujimoto, M., Okatani, Y., Nishiyama, T., Goh, T., Ito, E., Dainobu, T., Nishitani, A., Uemura, T., Sato, M.H., Thordal-Christensen, H., Tsutsumi, N., Nakano, A. and Ueda, T. (2011) A Membrane Trafficking Pathway Regulated by the Plant-Specific RAB GTPase ARA6. Nature Cell Biology, 13, 853-859.

https://doi.org/10.1038/ncb2270

[47] Uemura, T., Ueda, T., Ohniwa, R.L., Nakano, A., Takeyasu, K. and Sato, M.H. 
(2004) Systematic Analysis of SNARE Molecules in Arabidopsis. Dissection of the Post-Golgi Network in Plant Cells. Cell Structure and Function, 29, 49-65. https://doi.org/10.1247/csf.29.49

[48] Short, E.F., North, K.A., Roberts, M.R., Hetherington, A.M., Shirras A.D. and McAinsh, M.R. (2012) A Stress-Specific Calcium Signature Regulating an Ozone-Responsive Gene Expression Network in Arabidopsis. The Plant Journal, 71, 948-961. https://doi.org/10.1111/j.1365-313X.2012.05043.x

[49] Gupta, D.B., Rai, Y., Gayali, S., Chakraborty, S. and Chakraborty, N. (2016) Plant Organellar Proteomics in Response to Dehydration: Turning Protein Repertoire into Insights. Frontiers in Plant Science, 7, Article No. 460. https://doi.org/10.3389/fpls.2016.00460

[50] Johnston, S.C., Larsen, C.N., Cook, W.J., Wilkinson, K.D. and Hill, C.P. (1997) Crystal Structure of a Deubiquitinating Enzyme (Human UCH-L3) at 1.8 å Resolution. The EMBO Journal, 16, 3787-3796. https://doi.org/10.1093/emboj/16.13.3787

[51] Chen, L., Ren, F., Zhong, H., Jiang, W. and Li, X. (2010) Identification and Expression Analysis of Genes in Response to High-Salinity and Drought Stresses in Brassica napus. Acta Biochimica et Biophysica Sinica, 42, 154-164. https://doi.org/10.1093/abbs/gmp113

[52] Liu, Y.C., Wu, Y.R., Huang, X.H., Sun, J. and Xie, Q. (2011) AtPUB19, a U-box E3 Ubiquitin Ligase, Negatively Regulates Abscisic Acid and Drought Responses in Arabidopsis thaliana. Molecular Plant, 4, 938-946. https://doi.org/10.1093/mp/ssr030

[53] Hell, R. (1997) Molecular Physiology of Plant Sulphur Metabolism. Planta, 202, 138-148. https://doi.org/10.1007/s004250050112

[54] Martin, M.N., Tarczynski, M.C., Shen, B. and Leustek, T. (2005) The Role of 5'-Adenylyl Sulfate Reductase in Controlling Sulfate Reduction in Plants. Photosynthesis Research, 86, 309-323. https://doi.org/10.1007/s11120-005-9006-Z

[55] Herrmann, J., Nathin, D., Lee, S.G., Sun, T. and Jez, J.M. (2015) Recapitulating the Structural Evolution of Redox Regulation in Adenosine 5'-Phosphosulfate Kinase from Cyanobacteria to Plants. Journal of Biological Chemistry, 290, 24705-24714. https://doi.org/10.1074/jbc.M115.679514

[56] Lin, S.H., Kuo, H.F., Canivenc, G., Lin, C.S., Lepetit, M., Hsu, P.K., Tillard, P., Lin, H.L., Wang, Y.Y., Tsai, C.B., Gojon, A. and Tsay Y. (2008) Mutation of the Arabidopsis NRT1.5 Nitrate Transporter Causes Defective Root-to-Shoot Nitrate Transport. Plant Cell, 20, 2514-2528. https://doi.org/10.1105/tpc.108.060244

[57] Li, J.Y., Fu, Y.L., Pike, S.M., Bao, J., Tian, W., Zhang, Y., Chen, C.Z., Zhang, Y., Li, H.M., Huang, J., Li, L., Schroeder, J.I., Gassmann, W. and Gong, J. (2010) The Arabidopsis Nitrate Transporter NRT1.8 Functions in Nitrate Removal from the Xylem Sap and Mediates Cadmium Tolerance. Plant Cell, 22, 1633-1646. https://doi.org/10.1105/tpc.110.075242

[58] Peal, L., Jambunathan, N. and Mahalingam, R. (2011) Phylogenetic and Expression Analysis of RNA-Binding Proteins with Triple RNA Recognition Motifs in Plants. Molecules and Cells, 31, 55-64. https://doi.org/10.1007/s10059-011-0001-2

[59] Lorkovic, Z.J. (2009) Role of Plant RNA-Binding Proteins in Development, Stress Response and Genome Organization. Trends in Plant Science, 14, 229-236. https://doi.org/10.1016/j.tplants.2009.01.007

[60] Udvardi, M.K., Kakar, K., Wandrey, M., Montanri, O., Murray, J., Andraiankaja, A., Zhang, J.Y., Benedito, V., Hofer, J.M.I., Cheng, F. and Town, C.D. (2007) Legume Transcription Factors: Global Regulators of Plant Development and Response to the 
Environment. Plant Physiology, 144, 538-549.

https://doi.org/10.1104/pp.107.098061

[61] Agarwal, M., Hao, Y., Kapoor, A., Dong, C.H., Fujii, H., Zheng, X. and Zhu, J.K. (2006) A R2R3 Type MYB Transcription Factor Is Involved in the Cold Regulation of CBF Genes and in Acquired Freezing Tolerance. The Journal of Biological Chemistry, 281, 37636-37645. https://doi.org/10.1074/jbc.M605895200

[62] Dubos, C., Stracke, R., Grotewold, E., Weisshaar, B., Martin, C. and Lepiniec, L. (2010) MYB Transcription Factors in Arabidopsis. Trends in Plant Science, 15, 573-581. https://doi.org/10.1016/j.tplants.2010.06.005

[63] Zhang, Z., Liu, X., Wang, X., Zhou, M., Zhou, X., Ye, X. and Wei, X. (2012) An R2R3 MYB Transcription Factor in Wheat, TaPIMP1, Mediates Host Resistance to Bipolaris sorokiniana and Drought Stresses through Regulation of Defense- and Stress-Related Genes. New Phytologist, 196, 1155-1170.

https://doi.org/10.1111/j.1469-8137.2012.04353.x

[64] Li, W. X., Oono, Y., Zhu, J., He, X.J., Wu, J.M., Iida, K., Lu, X.Y., Cui, X., Jin, H. and Zhu, J.K. (2008) The Arabidopsis NFYA5 Transcription Factor Is Regulated Transcriptionally and Post Transcriptionally to Promote Drought Resistance. The Plant Cell, 20, 2238-2251. https://doi.org/10.1105/tpc.108.059444

[65] Stephenson, T.J., McIntyre, C.L., Collet, C. and Xue, G.P. (2011) TaNF-YB3 Is Involved in the Regulation of Photosynthesis Genes in Triticum aestivum. Functional and Integrative Genomics, 11, 327-340. https://doi.org/10.1007/s10142-011-0212-9

[66] Yang, T. and Poovaiah, B.W. (2002) A Calmodulin-Binding/CGCG Box DNABinding Protein Family Involved in Multiple Signalling Pathways in Plants. The Journal of Biological Chemistry, 277, 45049-45058. https://doi.org/10.1074/jbc.M207941200

[67] Li, X., Lei, H., Yafen, Z., Zhigang, O., Hong, Y., Zhang, H., Li, D. and Song, F. (2014) Tomato SR/CAMTA Transcription Factors SISR1 and SISR3L Negatively Regulate Disease Resistance Response and SISR1L Positively Modulates Drought Stress Tolerance. BMC Plant Biology, 14, Article No. 286.

https://doi.org/10.1186/s12870-014-0286-3

[68] Doherty, C.J., Van Buskirk, H.A., Myers, S.J. and Thomashow, M.F. (2009) Roles for Arabidopsis CAMTA Transcription Factors in Cold-Regulated Gene Expression and Freezing Tolerance. The Plant Cell, 21, 972-984.

https://doi.org/10.1105/tpc.108.063958

[69] Rodriguez, E., Chevalier, J., El Ghoul, H., Voldum-Clausen, K., Mundy, J. and Petersen, M. (2018) DNA Damage as a Consequence of NLR Activation. PLoS Genetics, 14, e1007235. https://doi.org/10.1371/journal.pgen.1007235

[70] Lee, S.K., Fletcher, A.G., Zhang, L., Chen, X., Fischbeck, J.A. and Stargell, L.A. (2010) Activation of a Poised RNAPII-Dependent Promoter Requires Both SAGA and Mediator. Genetics, 184, 659-672. https://doi.org/10.1534/genetics.109.113464

[71] Kagey, M.H., Newman, J.J., Bilodeau, S., Zhan, Y., Orlando, D.A., van Berkum, N.L., Ebmeier, C.C., Goossens, J., Rahl, P.B., Levine, S.S., Taatjes, D.J., Dekker, J. and Young, R.A. (2010) Mediator and Cohesin Connect Gene Expression and Chromatin Architecture. Nature, 467, 430-435. https://doi.org/10.1038/nature09380

[72] Kim, Y.J., Zheng, B., Yu, Y., Won, S.Y., Mo, B. and Chen X. (2011) The Role of Mediator in Small and Long Noncoding RNA Production in Arabidopsis thaliana. The EMBO Journal, 30, 814-822. https://doi.org/10.1038/emboj.2011.3

[73] Kidd, B.N., Cahill, D.M., Manners, J.M., Schenk P.M. and Kazan K. (2011) Diverse Roles of the Mediator Complex in Plants. Seminars in Cell and Developmental Bi- 
ology, 22, 741-748. https://doi.org/10.1016/j.semcdb.2011.07.012

[74] Mathur, S., Vyas, S., Kapoor, S. and Tyagi, A.K. (2011) The Mediator Complex in plants: Structure, Phylogeny, and Expression Profiling of Representative Genes in a Dicot (Arabidopsis) and a Monocot (Rice) during Reproduction and Abiotic Stress. Plant Physiology, 157, 1609-1627. https://doi.org/10.1104/pp.111.188300

[75] Sunkar, R., Chinnusamy, V., Zhu, J. and Zhu J.K. (2007) Small RNAs as Big Players in Plant Abiotic Stress Responses and Nutrient Deprivation. Trends in Plant Science, 12, 301-309. https://doi.org/10.1016/j.tplants.2007.05.001

[76] Thilagavathy, A. and Devaraj, V.R. (2015) Identification and Differential Expression Analysis of Conserved MicroRNAs under Salt Stress in Lablab purpureus (Hyacinth Bean). Journal of Environmental Science, Computer Science and Engineering and Technology, Section A, 5, 123-137.

[77] Zoschke, R., Nakamura, M., Liere, K., Sugiura, M., Börner, T. and Schmitz-Linneweber, C. (2010) An Organellar maturase Associates with Multiple Group II Introns. Procedings of National Academy of Science of the United states of America, 107, 3245-3250. https://doi.org/10.1073/pnas.0909400107

[78] Barthet, M.A. and Hilu, K.W. (2007) Expression of matK: Functional and Evolutionary Implications. American Journal of Botany, 94, 1402-1412.

https://doi.org/10.3732/ajb.94.8.1402

[79] Schmitz-Linneweber, C. and Small, I. (2008) Pentatricopeptide Repeat Proteins: A Socket Set for Organelle Gene Expression. Trends in Plant Science, 13, 663-670.

https://doi.org/10.1016/j.tplants.2008.10.001

[80] Zsigmond, L., Szepesi, A., Tari, I., Rigó, G., Király, A. and Szabados, L. (2012) Overexpression of the Mitochondrial PPR40 Gene Improves Salt Tolerance in Arabidopsis. Plant Science, 182, 87-93.

https://doi.org/10.1016/j.plantsci.2011.07.008

[81] Rodríguez-Navarro S. and Hurt E. (2011) Linking Gene Regulation to mRNA Production and Export. Current Opinion in Cell Biology, 23, 302-309. https://doi.org/10.1016/j.ceb.2010.12.002

[82] Sahu, P.P., Pandey, G., Sharma, N., Puranik, S., Muthamilarasan, M. and Prasad, M. (2013) Epigenetic Mechanisms of Plant Stress Responses and Adaptation. Plant Cell Reports, 32, 1151-1159. https://doi.org/10.1007/s00299-013-1462-x

[83] Lolas, I.B., Himanen, K., Grønlund, J.T., Lynggaard, C., Houben, A., Melzer, M., Lijsebettens, M.V. and Grasser, K.D. (2010) The Transcript Elongation Factor FACT Affects Arabidopsis Vegetative and Reproductive Development and Genetically Interacts with HUB1/2. The Plant Journal, 61, 686-697. https://doi.org/10.1111/j.1365-313X.2009.04096.x

[84] Luo, M., Hung, F., Yang, S., Liu, X. and Wu, K. (2014) Histone Lysine Demethylases and Their Functions in Plants. Plant Molecular Biology Reporter, 32, 558-565. https://doi.org/10.1007/s11105-013-0673-1

[85] Martinez-Seidel, F., Beine-Golovchuk, O., Hsieh, Y. and Kopka, J. (2020) Systematic Review of Plant Ribosome Heterogeneity and Specialization. Frontiers in Plant Science, 11, Article No. 948. https://doi.org/10.3389/fpls.2020.00948

[86] Sadder, M., Alsadon, A. and Wahb-allah, M. (2014) Transcriptomic Analysis of Tomato Lines Reveals Putative Stress-Specific Biomarkers. Turkish Journal of Agriculture and Forestry, 38, 700-715. https://doi.org/10.3906/tar-1312-17

[87] Tsujii, R., Miyoshi, K., Tsuno, A., Matsui, Y., Toh-e, A., Miyakawa, T. and Mizuta, K. (2000) Ebp2p, Yeast Homologue of a Human Protein That Interacts with Ep- 
stein-Barr Virus Nuclear Antigen 1, Is Required for pre-rRNA Processing and Ribosomal Subunit Assembly. Genes Cells, 5, 543-553. https://doi.org/10.1046/j.1365-2443.2000.00346.x

[88] Ascencio-Ibáñez, J.T., Sozzani, R., Lee, T.J., Chu, T.M., Wolfinger, R.D., Cella, R. and Hanley-Bowdoin L. (2008) Global Analysis of Arabidopsis Gene Expression Uncovers a Complex Array of Changes Impacting Pathogen Response and Cell Cycle during Geminivirus Infection. Plant Physiology, 148, 436-454.

https://doi.org/10.1104/pp.108.121038

[89] Huang, K.C., Lin, W.C. and Cheng, W.H. (2018) Salt Hypersensitive Mutant 9, a Nucleolar APUM23 Protein, Is Essential for Salt Sensitivity in Association with the ABA Signaling Pathway in Arabidopsis. BMC Plant Biology, 18, Article No. 40. https://doi.org/10.1186/s12870-018-1255-Z

[90] Ma, Y., Dias, M.C. and Freitas, H. (2020) Drought and Salinity Stress Responses and Microbe-Induced Tolerance in Plants. Frontiers in Plant Science, 11, Article No. 591911. https://doi.org/10.3389/fpls.2020.591911

[91] Xu, Y.H., Liu, R., Yan, L., Liu, Z.Q., Jiang, S.C., Shen, Y.Y., Wang, X.F. and Zhang, D.P. (2012) Light-Harvesting Chlorophyll $a / b$-Binding Proteins Are Required for Stomatal Response to Abscisic Acid in Arabidopsis. Journal of Experimental Botany, 63, 1095-1106. https://doi.org/10.1093/jxb/err315

[92] Lai, Y., Xu, B., He, L., Lin, M., Cao, L., Mou, S., Wu, Y. and He, S. (2011) Differential Gene Expression in Pepper (Capsicum annuum) Exposed to UV-B. Indian Journal Experimental Biology, 49, 429-437.

[93] Horie, Y., Ito, H., Kusaba, M., Tanaka, R. and Tanaka, A. (2009) Participation of Chlorophyll $b$ Reductase in the Initial Step of the Degradation of Light-Harvesting Chlorophyll a/b-Protein Complexes in Arabidopsis. The Journal of Biological Chemistry, 284, 17449-17456. https://doi.org/10.1074/jbc.M109.008912

[94] Yasuhito, S., Lee, S., Kim, Y., Park, O.K., Hörtensteiner, S. and Paek, N. (2014) Delayed Degradation of Chlorophylls and Photosynthetic Proteins in Arabidopsis Autophagy Mutants during Stress-Induced Leaf Yellowing. Journal of Experimental Botany, 65, 3915-3925. https://doi.org/10.1093/jxb/eru008

[95] Kusaba, M., Ito, H., Morita, R., Iida, S., Sato, Y., Fujimoto, M., Kawasaki, S., Tanaka, R., Hirochika, H., Nishimura, M. and Tanaka, A. (2007) Rice NON-YELLOW COLORING1 Is Involved in Light-Harvesting Complex II and Grana Degradation during Leaf Senescence. The Plant cell, 19, 1362-1375.

https://doi.org/10.1105/tpc.106.042911

[96] Stengel, A., Benz, J.P., Buchanan, B.B., Soll, J. and Bolter, B. (2009) Preprotein Import into Chloroplasts via the Toc and Tic Complexes Is Regulated by Redox Signals in Pisum sativum. Molecular Plant, 2, 1181-1197.

https://doi.org/10.1093/mp/ssp043

[97] Rabello, A.R., Guimarães, C.M., Rangel, P.H., Da Silva, F.R., Seixas, D., De Souza, E., Brasileiro, A.C.M., Spehar, C.R., Ferreira, M.E. and Mehta A. (2008) Identification of Drought-Responsive Genes in Roots of Upland Rice (Oryza sativa L). BMC Genomics, 9, Article No. 485. https://doi.org/10.1186/1471-2164-9-485 